\title{
UHF RFID LABEL NANOMETER PRINTING TECHNOLOGY AND ITS APPLICATION IN SMART LIBRARIES
}

\author{
Fujun Zhang, Jianming Cui
}

Preliminary communication

The emergence of RFID (radio frequency identification devices) tags solves the problem of inefficiencies caused by the use of traditional barcodes in libraries, but the cost of RFID tag printing has been high, resulting in its inability to be applied on a large scale. Compared with other printing means, nano-conductive ink printing has advantages since it can improve production efficiency, save costs and reduce pollution. Built based on radio frequency identification technology, smart libraries overcome the problem of a lot of manpower and time required by traditional libraries through the application of RFID labels. In addition, they have simpler processes, with higher efficiency and safety, and the borrowing of books is more convenient, with more frequent interactions. Hence, the promotion of the use of UHF (ultra-high frequency) RFID tags is of great significance.

Keywords: nano-printing; RFID; smart library; ultra-high frequency

Nanometarska grafička tehnologija UHF RFID naljepnica i njihova primjena u pametnim knjižnicama

Prethodno priopćenje Pojava RFID (radiofrekvencijski identifikacijski uređaji) rješava problem neučinkovitosti uzrokovanih uporabom tradicionalnih barkodova u knjižnicama, ali je cijena tiskanja RFID oznaka bila visoka, što je rezultiralo nemogućnošću njegove primjene u velikoj mjeri. U usporedbi s drugim sredstvima za tiskanje, nano-vodljivi tisak tinte ima prednosti jer može poboljšati učinkovitost proizvodnje, smanjiti troškove i smanjiti onečišćenje. Izrađene na temelju tehnologije prepoznavanja radijskih frekvencija, putem primjene RFID oznaka pametne knjižnice prevladavaju problem mnogo radne snage i vremena koje zahtijevaju tradicionalne knjižnice. Osim toga, one imaju jednostavnije procese, uz veću učinkovitost i sigurnost, a zaduživanje knjiga je prikladnije, s češćim interakcijama. Stoga je promocija uporabe RFID oznaka UHF (ultra-visoke frekvencije) od velikog značaja.

Ključne riječi: nano-tisak; pametna knjižnica; RFID; ultra-visoka frekvencija

\section{Introduction}

With the development of information technology, the problems faced by traditional libraries are becoming more and more serious. With huge amount of information in libraries, it is difficult for staffs to complete the borrowing and returning, sorting and uploading to shelves work of books rapidly with traditional barcodes. However, RFID technology [1] solves this problem. Compared with the traditional bar code recognition method, RFID tags have the advantages of convenient operation, large data storage capacity, fast processing speed and high security and are less affected by the environment. But they cannot yet be widely applied since their mass production is difficult due to high printing cost. Sun Liangquan, An Bing et al [2] found that the use of nano-copper ink printing can greatly reduce the printing costs of RFID tags. YongshikLee, Chung-Hwan Kim et al. [3] found through experiments that the radiation efficiency of antennas based on nano silver ink is better than the radiation efficiency of antennas printed with particulate silver ink, similar to the radiation efficiency of ordinary copper antenna. MiYongdi [4] held that RFID technology has been widely used in libraries and gradually become mature and it can greatly break through the existing RFID service with the UHF remote read and write function. The purpose of this paper is to reduce the production cost by studying the RFID tags of nano-conductive inks. Meanwhile, the advantages of UHF RFID tags applied in smart libraries are summarized, suggesting their possibility of being applied in a wider range.

\section{UHF RFID tag nano-printing process 2.1 UHF RFID tags}

Radio frequency identification (RFID) is a noncontact automatic identification communication technology [5]. With its advantages over other technologies, such as remote data transmission without manual intervention, good security and data storage capacity and fast data read speed, it is widely applied in industrial, commercial, transportation areas and other areas of automation management. An RFID tag consists of an antenna, a radio frequency module, a control module and a memory [6]. According to their different operating frequency, RFID tags are divided into low frequency, high frequency and ultra-high frequency types. UHF RFID tag operating frequency is between $850 \div 960$ $\mathrm{MHz}$, with a small antenna size and directional identification functions. The following is a picture of an ultra-high frequency tag.

As shown in Fig. 1, signals sent by the reader are received by the antenna and then converted into electrical signals. As the transponder of the ultra-high frequency band is backwardly scattering, the electrical signals it receives are small. So a voltage doubler circuit is set on the path to increase the voltage. In order to prevent the voltage from breaking the circuit, a voltage limiting circuit is then assembled, which is started when the voltage is large and stopped when the voltage is small. After going through two circuits, the voltage is within a certain range, where the power supply VDD is obtained through the voltage regulator circuit. The mediation circuit demodulates the signal received by the antenna from the high frequency signal and sends it to the digital part for processing. The modulation circuit modulates the transmitted signal in the digital portion onto the antenna. 
The digital section also includes a security module, which encrypts the entire tag. Because of its characteristics of long read-write distance and fast read-write speed, UHF
RFID tags are often used in the fields of logistics and libraries but not popular due to its high costs.

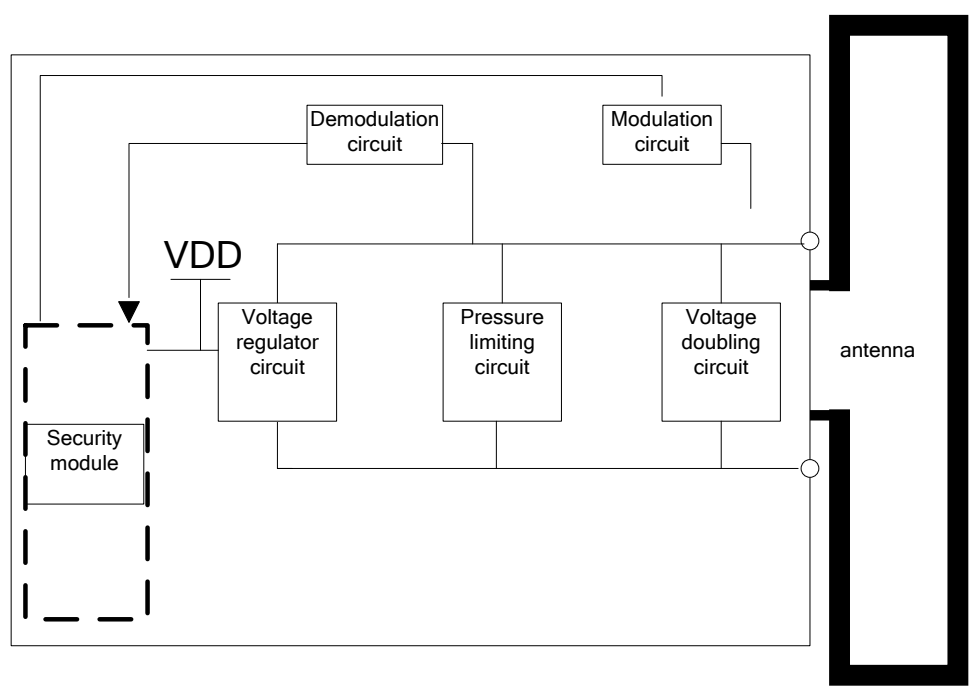

Figure 1 Diagram of an UHF RFID tag

\subsection{Nano-printing process}

RFID tags are made up of RFID antennas and RF chips [7], with their antennas made by winding method, etching method, electroplating method, hot stamping method and nano-printing method [8]. The nano-printing method combines nanomaterials with the printing process [9] which forms the antenna patterns by printing a nano conductive ink layer directly on the base. The printing methods include [10]: silk-screen printing, offset printing, gravure printing, flexographic printing and inkjet printing. Conductive ink mainly consists of conductive materials, connecting materials and additives. Different printing methods adopt different ink formulation and performance parameters, though, their conductive mechanisms are interlinked, mainly based on seepage theory and tunnelling theory. The volume fraction of the conductive material directly affects the rheological properties and electrochemical properties of the ink, thus affecting the quality of the tag antenna. This approach facilitates largescale assembly line production, with high efficiency, little metal material consumption, low cost and high precision. Above all, it is environmentally friendly, which adheres to the concept of green economy. As electroplating and etching processes are complex and can pollute the environment, Nano-printing method is widely used in the production of antennas with the birth of conductive ink, which is expected to overcome the above shortages of other printing methods.

\subsection{Specific printing methods and experiments}

The specific printing procedures of the methods mentioned above are as follows:

(1) Silk-screen printing forms images on a printing stock by making the ink pass through the printing graphic part under the impact of pressure.

(2) Offset printing uses the rubber to pass the graphic on the plate to the printing stock.
(3) Gravure imprints the ink in the pit directly onto the printing stock. The size and depth of the pit directly determine the thickness and density of the ink.

(4) Flexographic printing firstly passes the flexographic ink with low viscosity and good fluidity through the ink roller to the ink hole of the anilox roll, then uses a doctor blade to scrape off the excess ink that is filled in the ink hole and finally prints the ink remaining in the ink hole to the printing stock.

(5) Inkjet printing makes the ink erupted from the spray nozzle of an ink-jet printer under the joint effect of the oscillator and piezoelectric drive device. According to the printing data information, the ink droplets are selectively charged and selectively printed from the deflection electric field onto the printing stock.

In this study, the ink - jet printing of passive UHF RFID tags with conductive silver ink is studied.

\subsubsection{Experimental materials and equipment}

Materials: specially formulated conductive silver ink suitable for inkjet printing, with an ordinary packaging cardboard taken as the base.

Equipment: a Dimatix Materials Printer DMP-2831 printer with a $10 \mathrm{pl} \mathrm{nozzle.}$

\subsubsection{Experimental process}

Parameter setting: the spacing between the inkjet printing head and the base material: $0.5 \mathrm{~mm}$; flat plate temperature: $60^{\circ} \mathrm{C}$; inkjet temperature: $40^{\circ} \mathrm{C}$; inkjet voltage: $24 \mathrm{~V}$; inkjet frequency: $9 \mathrm{kHz}$; printing resolution: b423 dpi. Printed using the printer, with repeated printing in the same direction for twenty times, and sintering is required after printing. Since the time for low temperature sintering is long, ultraviolet light sintering is selected and solidification is realized through the formation of chemical bonds. It is set that the intensity of the UV light is enough to penetrate the printed conductive ink and prevent the 
only sintering on the surface. It is then connected to the sample with conductive silver epoxy.

(1) Comparison between the experimental labels made and the ultra-high frequency RFID tags made by screen printing which are purchased from the market.

(2) Testing of the threshold power and theoretical read range of passive UHF RFID tags using a tag tester.

\subsubsection{Experimental results and analysis} figure.

The comparison results are shown in the following
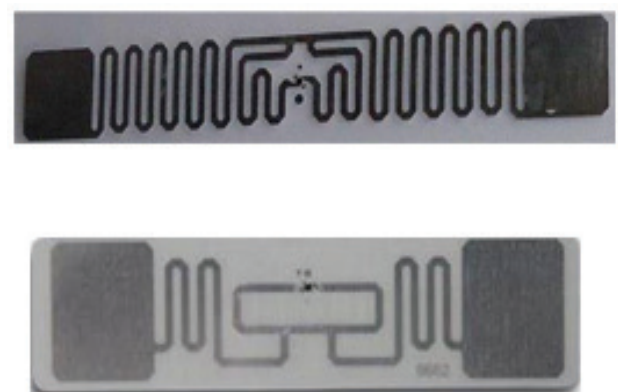

Figure 2 Appearance comparison of an inkjet printing label (up) and a screen printing label (down)

As shown in the figure, there are no obvious differences in the appearance of the two labels. The oscilloscope is an electronic measuring instrument that can measure the frequency and observe the current waveform. The optimum frequency for the printed UHF RFID tags measured by oscilloscopes is 900 to $960 \mathrm{MHz}$. Keep the reader power unchanged and the to be tested labels away from the card reader, until there is a card read error. The reading range measured in the UHF RFID identification band is $5 \div 6 \mathrm{~m}$.

The above results show that the frequency and read and write distance of UHF RFID tags for conductive silver ink inkjet printing are sufficient to meet the needs of longer read and write distances and higher read and write speed requirements, whereas the use of conductive copper inks can reduce the printing costs. Apart from the advantages of good material adaptability and simple process, inkjet printing can save materials, shorten the production cycle and its digital control features facilitate the mass production of UHF RFID tags which reduces the costs, meeting the requirement of green economy. With higher precision, it is suitable for printing miniaturization labels [11] and is the most promising method for ultra-high frequency RFID tag antenna manufacturing in the future.

\subsection{Price comparison of RFID labels and ordinary labels}

In this study, the price of the RFID labels and ordinary labels in the market was compared and the results are shown in Tab. 1.

Table 1 Price of RFID labels and ordinary labels

\begin{tabular}{|l|c|c|}
\hline & RFID labels & ordinary labels \\
\hline Price (yuan/piece) & 0.62 & 1.21 \\
\hline
\end{tabular}

As shown in the table, the price of an RFID label is 0.62 yuan while that of an ordinary label in the market is 1.21 yuan. Therefore, the RFID labels have lower cost and are more suitable for wide application.

\section{Application of UHF RFID tags in smart libraries 3.1 Application architecture design}

In traditional libraries, most works are realized through scanning bar code information [12] and updating information by connecting it to the backend system. After scanning, the books need to be placed back to their original shelves by the staffs, which waste a lot of manpower, resources and time. The emergence of RFID technology effectively solves the bar code management inefficiency and transforms the "counter" type of service into a "supermarket" type of service, i.e., a one-stop service.

As shown in the figure, the structure of the whole intellectual library is divided into five parts: self-service book system, security detection system, label conversion system, intelligent search system and automatic inventory system.

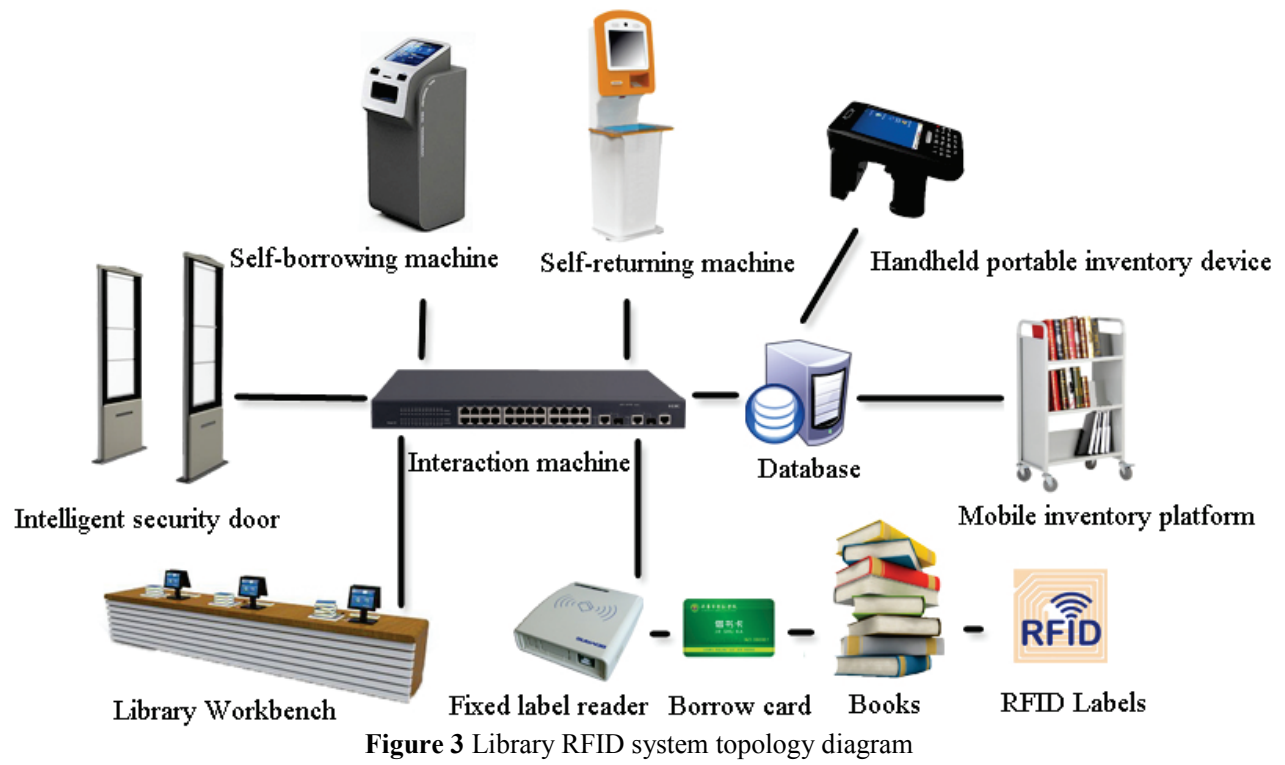




\subsection{New application design of RFID labels in smart libraries 3.2.1 User VIP mode}

With the non-contact remote read and large storage capacity characteristics of UHF RFID tags, information such as mobile phone number, mailing address, is input into the library card. An identification system is installed at the entrance guard to read and identify the library card information, according to which a VIP system is designed. For the VIP customers, they will be welcomed and seen off when they go in and out of the library and can have discounts; for child customers, their entering information including time and location can be sent to their parents through the phone numbers input to the cards; for the disabled customers and someone who needs help, the library staff should be informed of their coming in advance in order to assist them.

\subsubsection{Real time updating of data}

Through the installation of the RFID tag reader to bookshelves, the book information can be updated in real time. In this way, the information whether a book is taken from the shelf or another book is put on the shelf from other shelf can be read by the reader and updated to the database so that the staff can realize real time monitoring of the positions of books so as to timely correct their wrong positioning and reduce workload.

\subsubsection{Access to large data}

The book preference of users can be summarized based on the statistics of their borrowing records; popular bookshelves and categories can be summarized according to the times the books are taken from the shelves or borrowed; the books which are frequently browsed but not borrowed can also be summarized. The acquisition of these data is of great significance to the development of a library.

\subsubsection{Supervision of library staff}

RFID tags and readers cannot only realize the interaction between users and libraries, the interaction between users and librarians, but also enhance the interaction between librarians and libraries. With the RFID tags and readers, it is more convenient to achieve the librarian commuting, attendance statistics, and information collection of the inventory areas and times, which is beneficial to the management.

\subsection{Merits of applying RFID to smart libraries}

(1) Process simplification and efficiency improvement: RFID abandons the drawbacks of traditional bar code scanning which requires a fixed location and can realize fast, long distance, large data transmission with simple operation, providing a great convenience for both users and librarians.

(2) Positioning accuracy and error decrease: RFID can accurately locate the location of a book, making the borrowing more convenient and reducing the error possibility. Even if there is an error, it can be rapidly located and corrected, which is of great help to the librarians in contributing to improving the work efficiency [13] and reducing the workload.

(3) Automatic alignment and safety improvement: when a book with an RFID tag goes through the safety guard, it will be detected by the anti-theft system. Once abnormality is found, the alarm will be triggered to prevent the theft of books. At the same time, the system will automatically link the data flow and antitheft system, and enhance the accuracy of the antitheft system through comparing the screening of the records of borrowed books.

(4) Long life, long data: compared to traditional bar codes, RFID tags have larger data storage capacity and longer storage time. Due to their non-contact characteristics, they ensure at least one hundred thousand times of data reading. Besides, the tags have longer service life and are water and moisture resistant, less affected by the environment.

\section{Conclusion}

The use of nano-conductive ink printed RFID tags cannot only greatly reduce the cost of printing, expand the scope of application of labels, but also save resources, protect the environment, reduce ecological pressure. At present, the application of high-frequency RFID in libraries is relatively broad, but its cost is very high. Compared with high frequency RFID, UHF RFID is more suitable for a wide range of applications due to its low cost, despite the fact that it has shortcomings. By applying RFID into libraries to replace traditional bar codes, a new information resources interactive way is formed, which improves work efficiency, enhances the reliability and reliability of libraries, realizes a humanization service mode between users and libraries, strengthens the integration function of storing, borrowing and reading of libraries, makes the library system simpler, reduces errors, extends service space and time and deepens the service content. Hence, it is an inevitable trend for the intelligent development of libraries.

\section{References}

[1] Wei, W.; Zhang, L.; Yang, B. et al. The Research of Library's Auto-borrowed and Return Books Based on RFID Technology. // International Journal of Advancements in Computing Technology. 5, 7(2013), pp. 106-115. https://doi.org/10.4156/ijact.vol5.issue7.13

[2] Sun, L. Q.; Bin, A. N.; Jian, L. I. et al. Nano copper conductive ink printed RFID tag. // Electronics Process Technology. 34, 1(2013), pp. 6-9.

[3] Lee, Y.; Kim, C. H.; Shin, D. Y. et al. Printed UHF RFID antennas with high efficiencies using nano-particle silver ink. // Journal of Nanoscience \& Nanotechnology. 11, 7(2011), pp. 6425-6428. https://doi.org/10.1166/jnn.2011.4390

[4] Mi, Y. The Practical Application of UHF RFID in Libraries. // Library Journal. 2(2011), pp. 40-42.

[5] Liu, G.; Wan, Z. Summarize of RFID technology and typical application. // Cross Strait Quad-Regional Radio Science and Wireless Technology Conference. IEEE, (2011), pp. 1032-1036.

[6] Nakamura, K.; Umeda, Y.; Takyu, O. The resonance design including the diode in the power supply circuit of a UHF 
passive RFID tag. // Ieice Technical Report. 108, 334(2008), pp. 23-28.

[7] Hui, W. Y.; Bing, L. L.; Liu, L. K. P. EPC RFID technology for library applications. // Measurement and Control - London - Institute of Measurement and Control. 46, 1(2013), pp. 26-30. https://doi.org/10.1177/002029401304600104

[8] $\mathrm{Li}, \mathrm{C}$. Radio frequency identification (rfid) tag and manufacturing methods thereof. // VdiBuch. 25, 1-2(2014), pp. 119-131.

[9] Wang, L. UHF RFID Tag Based on the Nano-printing Process and Its Application in the Smart Library. // New Century Library. 2(2014), pp. 52-55.

[10] Suganuma, K. Printing Technology. // Introduction to Printed Electronics. Springer New York, 2014:23-48. https://doi.org/10.1007/978-1-4614-9625-0_2

[11] Virtanen, J.; Virkki, J.; Elsherbeni, A. Z. et al. A Selective InkDeposition Method for the Cost-Performance Optimizationof Inkjet-Printed UHF RFID Tag Antennas. // International Journal of Antennas \& Propagation. 3(2012), pp. 184-195. https://doi.org/10.1155/2012/801014

[12] Wu T. Y.; Yeh K. C.; Chen R. S. et al. Integrated library service application platform based on the smart book shelf. // Malaysian Journal of Library \& Information Science. 16, 3(2011), pp. 103-119.

[13] Yuan, Z. X. Construction of the Intelligent Library Management System Based on RFID. // Computer Knowledge and Technology. 27(2014), pp. 6517-6518.

[14] Dong, J. Application Analysis of HF RFID and UHF RFID in Library. // Journal of Modern Information. 32, 8(2012), pp. 162-164.

\section{Authors' addresses}

\section{Fujun Zhang, master}

(Corresponding author)

Library of Shandong University of Science and Technology,

No. 579 Qianwangang Road, Huangdao District, Qingdao City,

Shandong Province, 266590, China

E-mail:zhang_fujun@sina.com

\section{Juanming Cui, master}

College of Computer Science and Engineering, Shandong

University of Science and Technology, Qingdao, Shandong,

266590, China 